\title{
Adult and Near-Adult Height in Patients with Severe Insulin-Like Growth Factor-I Deficiency after Long-Term Therapy with Recombinant Human Insulin-Like Growth Factor-I
}

\author{
Philippe F. Backeljauw ${ }^{a} \quad J^{\prime}$ oyce Kuntze ${ }^{b}$ James Frane ${ }^{c}$ Ali S. Calikoglu ${ }^{d}$ \\ Steven D. Chernausek ${ }^{\mathrm{e}}$ \\ ${ }^{a}$ Cincinnati Children's Hospital Medical Center, Cincinnati, Ohio, ${ }^{b}$ Clinical Consultant, Burfordville, Mo., \\ 'Statistical Consultant, Santa Monica, Calif., ${ }^{d}$ University of North Carolina at Chapel Hill, Chapel Hill, N.C., and \\ e University of Oklahoma Health Sciences Center, Oklahoma City, Okla., USA
}

\section{Key Words}

Growth · Insulin-like growth factor-I therapy · Severe

insulin-like growth factor-I deficiency

\begin{abstract}
Background: Treatment with recombinant human insulinlike growth factor-I (IGF-I) stimulates linear growth in children with severe IGF-I deficiency (IGFD). Aims: To evaluate the efficacy and safety of treatment with IGF-I in patients with severe IGFD treated until adult or near-adult height. Methods: Twenty-one children with severe IGFD were treated until adult or near-adult height under a predominantly open-label design. All patients were naive to IGF-I. Recombinant human IGF-I was administered subcutaneously in doses between 60 and $120 \mu \mathrm{g} / \mathrm{kg}$ twice daily. Nine patients received additional therapy with gonadotropinreleasing hormone (GnRH) analog for a mean period of $2.9 \pm 1.8$ years. Results: Mean duration of treatment was 10.0 years. Mean height velocity increased from $3.1 \mathrm{~cm} /$ year prior to treatment to $7.4 \mathrm{~cm} /$ year during the first year of treatment. Height velocities during the subsequent years were lower, but remained above baseline for up to 12 years. Cumulative mean $\Delta$ height SD score at (near) adult height was +2 . The observed mean gain in height was $13.4 \mathrm{~cm}$ more
\end{abstract}

\begin{tabular}{ll}
\hline KARGER & $\begin{array}{l}\text { ( } 2013 \text { S. Karger AG, Basel } \\
1663-2818 / 13 / 0801-0047 \$ 38.00 / 0\end{array}$ \\
$\begin{array}{l}\text { E-Mail karger@karger.com } \\
\text { www.karger.com/hrp }\end{array}$ & $\begin{array}{l}\text { This is an Open Access article licensed under the terms of the } \\
\text { Creative Commons Attribution-NonCommercial 3.0 Un- } \\
\text { ported license (CC BY-NC) (www.karger.com/OA-license), } \\
\text { applicable to the online version of the article only. Distribu- } \\
\text { tion permitted for non-commercial purposes only. }\end{array}$
\end{tabular}

than had been expected without treatment. The adult height achieved by the patients also treated with $\mathrm{GnRH}$ analog was not different from those who received IGF-I therapy alone. There were no new safety signals identified in these patients, a subset of those previously reported. Conclusion: Longterm therapy with IGF-I improves adult height of patients with severe IGFD. Most patients did not bring their heights into the normal adult range.

Copyright ๑ 2013 S. Karger AG, Basel

\section{Introduction}

Recombinant human insulin-like growth factor-I (IGF-I) replacement therapy has been evaluated for children with severe IGF-I deficiency (IGFD), and is approved for this specific indication [height SD score $\leq-3$, and IGF-I SD score $\leq-3$ for the United States, or IGF-I $<2.5$ th percentile for the European Union, and normal or elevated growth hormone (GH)] [1,2]. Most, if not all, of the growth-promoting effects of $\mathrm{GH}$ in humans occur through stimulation of IGF-I production, both by the liver and other tissues [3]. Therefore, a severe deficiency in IGF-I production can be expected to result in profound growth retardation. Severe IGFD can be due to a variety 
Table 1. Patient subcategories based on underlying diagnosis

\begin{tabular}{|c|c|}
\hline Patients $(\mathrm{n}=21)$ & Clinical or molecular diagnosis \\
\hline $\begin{array}{l}\text { GHIS with proven GH } \\
\text { receptor defect }(n=6)\end{array}$ & $\begin{array}{l}\text { - Homozygous nonsense mutation in exon } 7(\mathrm{c} .703 \mathrm{C}>\mathrm{T}) \text { causing a stop codon (p.Arg217X) in } \\
2 \text { patients } \\
\text { - Homozygous nonsense mutation in exon } 4(\mathrm{c} .181 \mathrm{C}>\mathrm{T}) \text { causing a stop codon (p.Arg43X) in } 2 \text { patients } \\
\text { - Homozygous missense mutation in exon } 6(\mathrm{c} .509 \mathrm{~A}>\mathrm{G}) \text { (p.Asp152Gly) } \\
\text { - Heterozygous splice mutation in exon } 4(\mathrm{c} .266+1 \mathrm{G}>\mathrm{A}) \text { (p.Asn28ArgfsX41) (exon } 4 \text { skipping) }\end{array}$ \\
\hline Antibodies to $\mathrm{GH}(\mathrm{n}=5)$ & GH gene deletion type $1 \mathrm{~A}$ \\
\hline \multicolumn{2}{|c|}{$\begin{array}{l}\text { The patients with proven GH receptor defect had their diagnosis of GHIS confirmed by genetic testing. The GHIS-clinical patient } \\
\text { group did not undergo genetic testing, but all had the GH receptor phenotype and fit the study inclusion criteria (including extremely } \\
\text { low or undetectable GH binding protein) - they had presumed GH receptor deficiency. } \\
\mathrm{c}=\text { Coding DNA sequence; } \mathrm{p}=\text { protein sequence; } \mathrm{X}=\text { stop codon. }\end{array}$} \\
\hline
\end{tabular}

of causes, including - but not limited to - defects in GH action, either at the $\mathrm{GH}$ receptor or post-receptor signaling level $[4,5]$. Prior reports have shown that IGF-I therapy can stimulate growth in children who have severe (primary) IGFD due to GH receptor abnormalities or GH insensitivity, and in those who have developed GH-neutralizing antibodies to GH therapy [1, 6-9]. However, the effect of such therapy with IGF-I on adult height has been assessed in only a few patients [1]. We now report the adult and near-adult height of a cohort of 21 children treated for a mean duration of 10.0 years.

\section{Subjects and Methods}

\section{Subjects}

Twenty-one children with severe IGFD were diagnosed by pediatric endocrinologists participating in the GH insensitivity syndrome (GHIS) collaborative group, and were referred to one of two centers. All patients, naive to therapy with IGF-I, were studied either at Cincinnati Children's Hospital Medical Center or the University of North Carolina at Chapel Hill. The study was conducted in accordance with national and international ethical and regulatory standards. The experimental protocol and informed consent documents were reviewed and approved by the institutional review boards of both participating sites. Informed consent and assent were obtained respectively from the parents and, when applicable, the patients. Preliminary data from these subjects have been reported previously $[1,7]$. This report describes 21 of the study subjects with severe IGFD who received continuous treatment with IGF-I until (near) adult height. The initial study entry criteria were: age older than 2 years, height SD score $<-2$ for age and sex, IGF-I serum concentration SD score $<-2$ for age and sex, growth rate $<50$ th percentile for age and evidence of GH resistance/insensitivity. The GH insensitivity was further confirmed as failure to increase serum IGF-I concentration by more than $50 \mathrm{ng} / \mathrm{ml}$ after 4 daily subcutaneous $\mathrm{GH}$ injections of $0.1 \mathrm{mg} / \mathrm{kg}$. For those patients with GHIS due to a proven or presumed GH receptor defect, random or stimulated $\mathrm{GH}$ concentrations were $\geq 10 \mathrm{ng} / \mathrm{ml}$. Children who had developed growth-attenuating antibodies during $\mathrm{GH}$ treatment all had antibodies with a GH-binding capacity $>10 \mu \mathrm{g} / \mathrm{ml}$. Children were excluded if they had a prior or active malignancy, major organ dysfunction, were on treatment with medications that would diminish growth, or had clinically significant abnormalities of cardiac function or rhythm. The different subcategories of patients are described in table 1 . Of the 21 patients, 16 had a diagnosis of GHIS leading to severe primary IGFD. In 6 of them a molecular defect of the $\mathrm{GH}$ receptor was identified. In 10 other patients (GHIS-clinical) no genetic testing was done. Five of the 21 patients had GHIS due to a GH gene deletion leading to severe secondary IGFD. Of the latter group, 3 had prior shortterm exposure to GH therapy.

\section{Medications}

Recombinant human IGF-I (mecasermin, Increlex ${ }^{\circledR}$ ) was provided by Genentech, Inc. (South San Francisco, Calif., USA) at first, later by Tercica, Inc. (Brisbane, Calif., USA), and then by Ipsen Biopharmaceuticals, Inc. (Basking Ridge, N.J., USA). Nine of the patients also received gonadotropin-releasing hormone $(\mathrm{GnRH})$ analog (leuprolide acetate, goserelin, or triptorelin) during a portion of the treatment period, in order to delay puberty.

\section{Study Procedures}

Subjects began treatment at an IGF-I dose of $40 \mu \mathrm{g} / \mathrm{kg}$ subcutaneously twice a day. The dose was increased by $40-\mu \mathrm{g} / \mathrm{kg}$ increments, usually within a 2 -week period, to $120 \mu \mathrm{g} / \mathrm{kg}$ subcutaneously twice a day. At the study inception, some children received lower doses (40-80 $\mu \mathrm{g} / \mathrm{kg}$ twice daily) for the first several months. Two subjects were treated with a higher dose of IGF-I $(150 \mu \mathrm{g} / \mathrm{kg}$ twice daily) during some of their pubertal years. Subjects were evaluated at regular intervals: monthly during the first year of treatment, bimonthly during the second year, every 3 months for 
years 3 and 4, and twice per year thereafter. Scheduled study visits included review of the interval medical history and a recording of adverse events, anthropometry, and physical examination. The height measurements were obtained using a wall-mounted stadiometer. Radiology and laboratory assessments included a radiograph of the left hand and wrist for bone age (BA), read centrally at the Fells Institute, Yellow Springs, Ohio (now part of Lifespan Health Research Center, Dayton, Ohio, USA) using the FELS method [10]. Whole-body bone mineral density (BMD) and fat mass measurements were done using dual-energy X-ray absorptiometry (DXA, QDR-1000; Hologic, Inc., Waltham, Mass., USA). Echocardiography was done on a yearly basis, using a Sonos 1500 cardiac ultrasound machine (Hewlett-Packard Co., Andover, Mass., USA). Before therapy, after 6 and 12 months, and every year of treatment thereafter, measurements of kidney and spleen were obtained by ultrasonography. Hematological indices, serum chemistry panel, glucose, insulin, hemoglobin $\mathrm{A}_{1 \mathrm{c}}\left(\mathrm{Hb}_{1 \mathrm{c}}\right)$, lipids, calcium, phosphorus, liver enzymes, thyroid function tests, IGF-I, and insulin-like growth factor binding protein-3 (IGFBP-3) were monitored throughout the study period.

\section{Efficacy Endpoints and Statistics}

The 21 subjects analyzed in this study make up a subset of patients from a larger cohort previously reported on [1,7]. Adult/ near-adult height and annual height velocity were the primary efficacy endpoints. Height SD score was computed using the Centers for Disease Control and Prevention (CDC) age- and gender-dependent means and SD scores [11]. Because heights were not always measured at the exact 1-year intervals, some annual heights were imputed by interpolation using the closest dates before and after the anniversary of treatment initiation. Adult/near-adult height was defined as and evaluated in all subjects whose most recent BA was at least 16 years for males and 14 years for females. The adult height that subjects might have reached without IGF-I treatment was predicted using the Laron syndrome growth charts, which constitute a reference range for patients with $\mathrm{GH}$ receptor abnormalities [12].

Height velocity during each year of treatment was compared with pretreatment height velocity using a two-sided paired $t$ test at a significance level of 0.05 .

\section{Results}

\section{Effects of IGF-I Treatment on Growth, Adult Height and Body Composition}

Some of the baseline characteristics are displayed in table 2. The mean duration of treatment was 10.0 years (range 3.6-19.3). The average dose of IGF-I was $113 \mu \mathrm{g} / \mathrm{kg}$ given twice daily. Treatment with IGF-I stimulated linear growth independent of the degree of shortness or diagnostic category. The mean baseline height velocity $(3.1 \mathrm{~cm} /$ year) increased to $7.4 \mathrm{~cm} /$ year during the first year of treatment $(\mathrm{p}<0.0001)$. Although the mean growth velocities after the first year of therapy were lower, they remained above baseline for up to 12 years of therapy (fig. 1a). Mean height velocity during the second year of
Table 2. Baseline characteristics for 21 subjects with severe IGFD treated with recombinant human IGF-I until adult/near-adult height

\begin{tabular}{lrr}
\hline Characteristic & $\mathrm{n}(\%)$ & Mean \pm SD \\
\hline GH receptor deficiency (or GHIS) & $16(76)$ & \\
GH gene deletion + GH antibodies & $5(24)$ & \\
Female & $9(43)$ & \\
Age, years & & $7.4 \pm 4.7$ \\
Bone age, years & & $4.9 \pm 3.5$ \\
Height SD score & $-6.6 \pm 2.1$ \\
Weight for age SD score & $-7.2 \pm 5.7$ \\
Pretreatment height velocity, cm/year & & $3.1 \pm 2.0$ \\
\hline
\end{tabular}

therapy was $5.6 \mathrm{~cm} /$ year and ranged from 3.9 to $5.0 \mathrm{~cm} /$ year during years $3-12$. The mean change in height SD score at (near) adult height was +1.9 (range +0.1 to +4.7 ) . There was significant variability in the change in height SD score, in the sense that 9 patients improved their height SD score, at final analysis, with +2.0 or more, whereas 12 patients only had an improvement in height SD score by +1.7 or less. Figure $1 \mathrm{~b}$ illustrates the cumulative $\Delta$ height SD score per study year. The individual growth curves for height are shown in figure $2 \mathrm{a}$ and $\mathrm{b}$ for respectively 12 males and 9 females. Review of the individual growth curves shows that, after initial catch-up growth, linear growth is parallel to the CDC normative growth curves for the US population. Only 3 patients reached a height within the normal range (i.e. SD score -2 or above). Most other patients still improved their height but did not experience continued catch-up growth. When the patients with $\mathrm{GH}$ receptor deficiency (proven or presumed GH receptor defect) were compared to the patients with GH gene deletion, the former group was slightly younger (mean ages 7.1 versus 8.4 years) at the beginning of therapy. They were also taller: mean height SD score was -6.2 versus -8.0 , respectively, but mean time on IGF-I therapy was about 22 months longer: 10.5 versus 8.7 years. Despite this, mean $\Delta$ height SD scores were similar: +1.9 for the $\mathrm{GH}$ receptor deficiency subgroup, versus +1.7 for the $\mathrm{GH}$ gene deletion subgroup. However, this translated to a change in height minus the expected change without treatment of $15.1 \pm 8.2 \mathrm{~cm}$ for the $\mathrm{GH}$ receptor deficiency subgroup versus $7.9 \pm 8.5 \mathrm{~cm}$ for the $\mathrm{GH}$ gene deletion group.

Only 1 patient had onset of puberty prior to commencing IGF-I therapy (thelarche by 12 years). When we observed that several of our patients began puberty at a normal age, this led to a decision to introduce therapy to pro- 


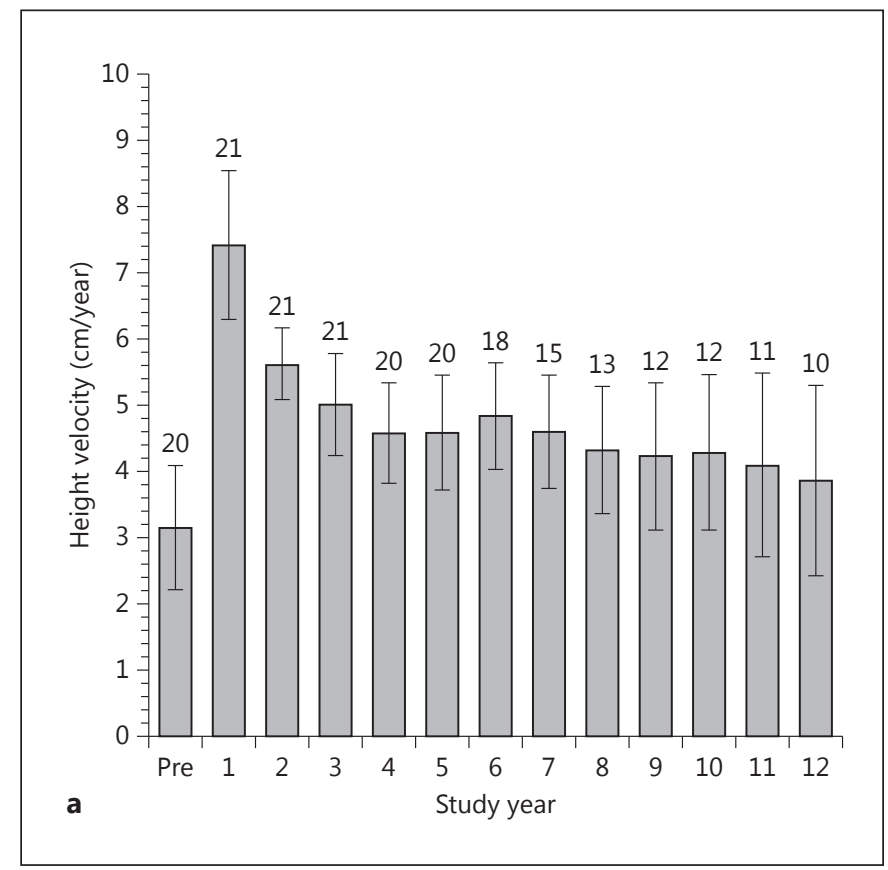

Fig. 1. a Pretreatment and on-treatment height velocity for the 21 patients with severe IGFD treated with recombinant human IGF-I until (near) adult height. The numbers above each bar indicate the numbers of patients per treatment period (with the declining numbers of patients representing longer treatment for fewer patients, not patient drop-out prior to (near) adult height).

long the time for growth. Therefore, 9 subjects were also treated with $\mathrm{GnRH}$ analog therapy (on average for $2.9 \pm 1.8$ years). These patients had similar baseline means for chronological age (CA) (7.7 years) and height SD score $(-6.3)$ as the patients who were treated solely with IGF-I (7.2 years, height SD score -6.8). Both these subgroups showed a similar response for $\Delta$ height SD score: $+2.0 \pm 1.6$ versus $+1.8 \pm 0.8$, respectively.

The adult height that subjects might have reached without IGF-I treatment was predicted using the Laron syndrome growth charts. We assumed that the growth of our patients, if left untreated, would occur at an average rate as reported for other untreated Laron syndrome patients [12]. The height each subject gained - relative to the expected height gain in absence of treatment - is shown in figure 3. The mean gain in height was, on average, $13.4 \mathrm{~cm}$ more than expected without treatment. Again, the great variability in treatment response is seen: 11 patients improved their adult height by $15 \mathrm{~cm}$ or more, whereas 10 other patients' adult height was only improved by $11 \mathrm{~cm}$ or less.

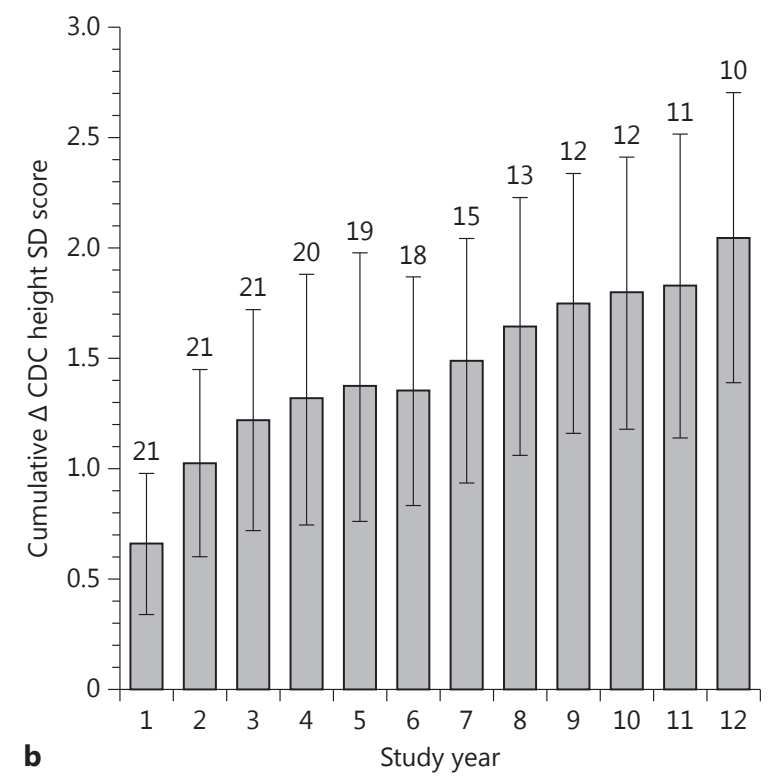

b Cumulative $\Delta$ height SD score for the 21 patients with severe IGFD treated with recombinant human IGF-I until (near) adult height. The numbers above each bar indicate the patient numbers per treatment period (with the declining numbers representing longer treatment for fewer patients, not patient drop-out prior to (near) adult height).
Statural growth was accompanied by weight gain. The mean SD score for weight changed from $-7.2( \pm 5.7)$ at baseline to $-2.7( \pm 3.0$, range -9.2 to +1.5$)$ at the end of the IGF-I therapy. Mean body mass index SD score at the beginning of treatment was $-0.3 \pm 1.0$ and increased in most patients, so that the mean body mass index SD score at treatment discontinuation was $+0.5( \pm 1.2$, range -2.0 to $+2.2, \mathrm{n}=21)$. The total body fat percentage, as measured by DXA, increased from $30.1 \pm 7 \%$ (range 18.7-46.4), when measured at the start of therapy, to $35.1 \pm 7 \%$ (range 23.6-50.6) at the last measurement $(\mathrm{n}=18)$. The $\Delta \%$ fat (whole-body) by DXA was $+5.1 \pm 4.2$ (range -5.7 to +14.4 ) over 9.2 years of IGF-I therapy. At the same time, the whole-body lean tissue by DXA decreased form $67.5 \pm 7.1 \%$ (range 50.8-71.8) to $62.0 \pm 6.9 \%$ (range 46.5-72.5).

\section{Effects on Bone Maturation and Organ Growth}

Skeletal maturation was delayed before IGF-I therapy: average CA was 7.4 years, while average BA was 4.9 years. At the time of the last BA assessment, the average CA was 17.7 years, and the average bone maturation was 


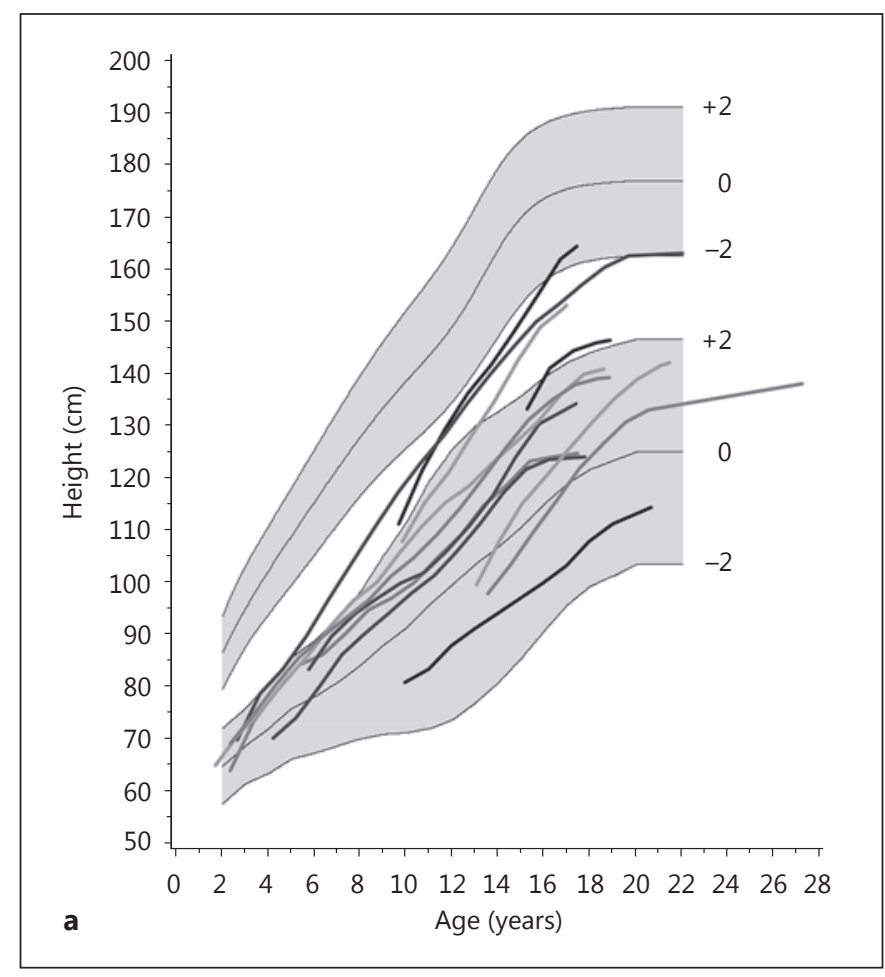

Fig. 2. a Individual growth during IGF-I therapy for 12 male patients, compared with the US National Center for Health Statistics standards (upper shaded area) and the mean \pm 2 SD for height for untreated Laron syndrome patients (lower shaded area). The growth curves for Laron syndrome constitute a reference range for patients with presumed $\mathrm{GH}$ receptor abnormalities [12].

15.9 years. The mean BA-to-CA ratio changed from 0.6 at baseline to 0.9 at the end of the IGF-I therapy. However, figure 4 illustrates that the skeletal maturation typically progressed in accord with the advancing CA during therapy. It should be noted that 9 patients were on average $2.9 \pm 1.8$ years on treatment with GnRH analogs (the duration of $\mathrm{GnRH}$ analog treatment varied from 0.6 to 6.4 years). It is possible that patients within this subgroup would have experienced a more rapid skeletal maturation had they received IGF-I therapy alone. A subanalysis of those treated only with IGF-I $(\mathrm{n}=12)$ yielded a mean change in BA of $10.9 \pm 3.7$ years over a treatment period of $9.6 \pm 3.6$ years. This contrasts with a change in BA of $11.0 \pm 5.0$ years over $11.0 \pm 5.5$ years of therapy for the GnRH + IGF-I group $(n=9)$, with a mean $\triangle B A / \triangle C A$ of $1.19 \pm 0.3$ versus $1.05 \pm 0.1$, respectively (fig. 4 ).

The effect of IGF-I therapy on whole-body BMD was measured by DXA (Hologic). Before therapy, BMD SD score was at or below -2 for several patients. There was a

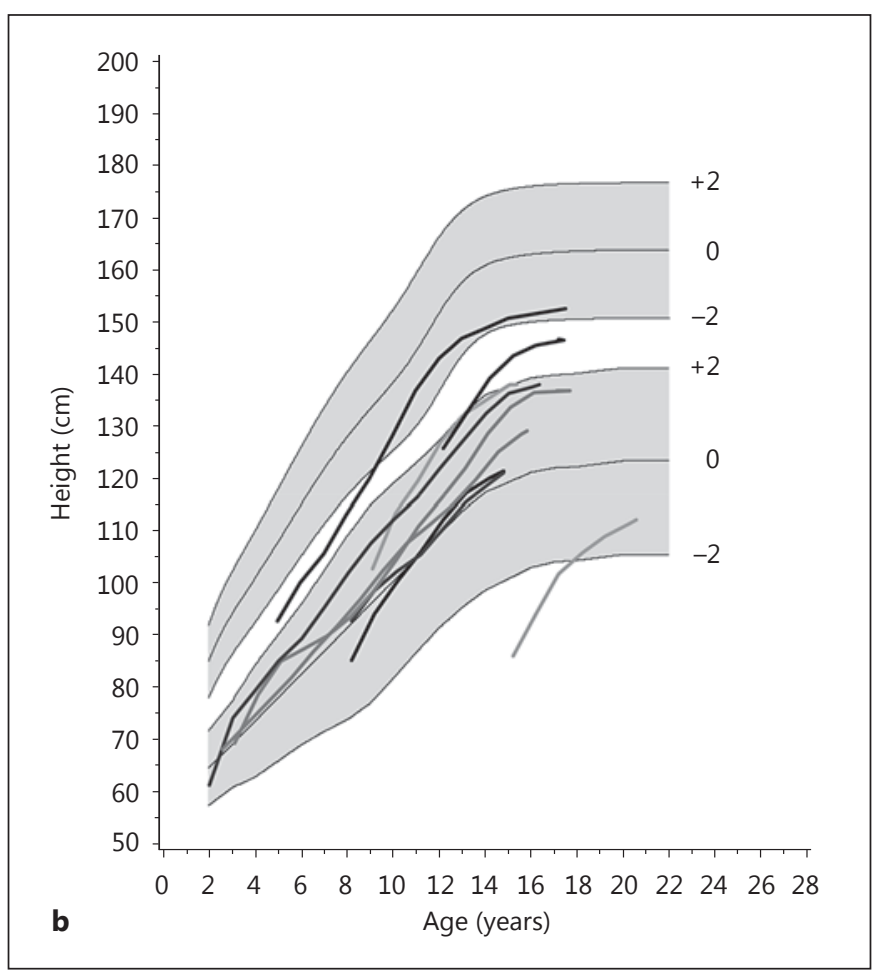

b Individual growth during IGF-I therapy for 9 female patients, compared with the US National Center for Health Statistics standards (upper shaded area) and the mean \pm 2 SD for height for untreated Laron syndrome patients (lower shaded area). The growth curves for Laron syndrome constitute a reference range for patients with presumed $\mathrm{GH}$ receptor abnormalities [12].

lot of variation in the observed BMD increments (online suppl. fig. 1; for all online supplementary material, see www.karger.com/doi/10.1159/000351958). Several patients had significant increases in BMD - beyond what was expected based on growth alone. Some of the observed changes in BMD may represent the effect of increased bone volume, a well-known caveat of BMD assessment with DXA. However, slowing of the bone mineralization was not observed, even with the 9 patients treated concurrently with GnRH analog therapy included.

Renal growth data were available in 11 males and 8 females, with first ultrasonography done at or near the time of IGF-I treatment initiation. Renal size and growth, in function of height, is shown in figure 5 (using the mean for the left and right renal lengths). The initial examinations revealed renal lengths that were low for age but low-normal for height. Kidney size increased during IGF-I treatment, and 6 patients ( 3 males, 3 females) had a renal lengthfor-height SD score at or above +2 at completion of IGF-I 


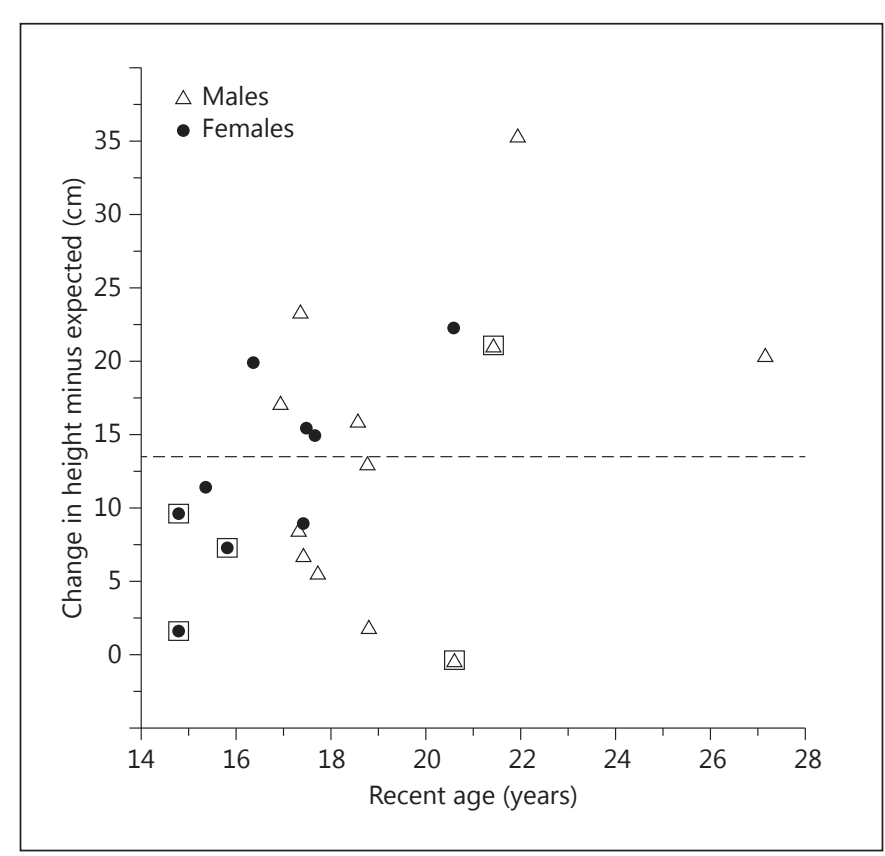

Fig. 3. Change in height achieved at the end of IGF-I therapy for 21 patients with severe IGFD, relative to their expected change in height, based on the assumption that the patients would have grown equivalent to untreated patients with Laron syndrome [12]. The dotted horizontal line indicates a mean gain in height of $13.4 \mathrm{~cm}$ more than expected without treatment. The squared dots or triangles indicate $\mathrm{GH}$ gene deletion patients.

therapy. Three of these patients were considered good responders and achieved an adult height SD score at or above -2 ; the other 3 patients did not have the same favorable growth response. No structural abnormalities of the kidneys were noted by ultrasound. Renal function remained normal, by determination of normal serum electrolytes and creatinine clearance (mean $137 \pm 29 \mathrm{ml} / \mathrm{min} / 1.73 \mathrm{~m}^{2}$, $\mathrm{n}=18$ ), while urinalyses did not yield proteinuria.

Spleen growth was also followed throughout the treatment period for 19 of the subjects ( 11 males, 8 females). Spleen length SD score for age was computed using the norms from Rosenberg et al. [13]. At baseline, average spleen length was small (12/19 patients had a spleen length SD score $<-2$ ) and an increase in spleen length was observed for the majority of patients. However, nearly all patients had spleen sizes within the normal range at the end of treatment. Only 1 subject had a spleen length SD score for age $>+2$ at the end of therapy. This patient experienced most of the spleen growth during the first 2 years of treatment and further growth occurred parallel with normal spleen growth during the remaining treatment years.

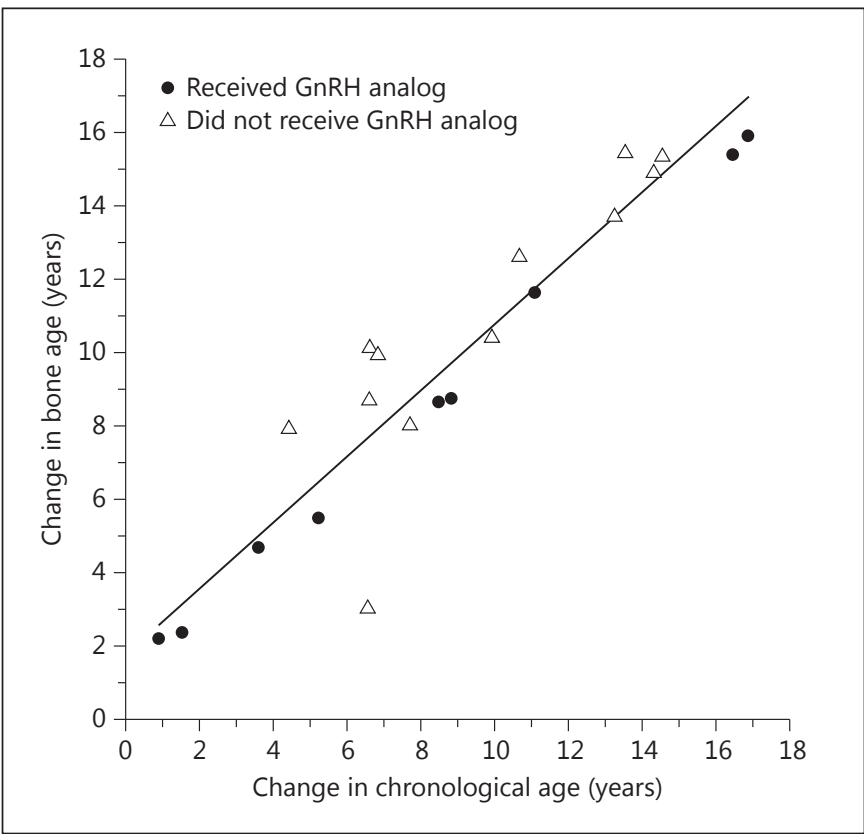

Fig. 4. Change in BA versus change in CA for 21 patients with nearadult/adult height. The line in the figure shows the regression line using all subjects as a single group.

\section{Effects on Facial Growth}

Cephalometric investigations, to evaluate the growth of the facial bony structures, are available for the first 6 years of IGF-I treatment in a subset of 8 patients. Before therapy, these patients had reduced facial dimensions with a small, retrognathic mandible and maxilla. After 6 years of therapy with IGF-I, most patients were still behind with their craniofacial development, but both linear and angular craniofacial parameters had improved. There did not appear to be any evidence of acromegaloid growth. The changes noted in the facial bones were accompanied by growth of the soft tissues of the face, which was more obvious when the patients were undergoing pubertal changes. The details of the cephalometric studies are the topic of a separate paper.

\section{Effects on Cardiac Function}

The effect of IGF-I therapy on cardiac function was followed by echocardiography and data were available on 19 patients. Normal intracardiac anatomy and ventricular function was observed in 15 patients. One patient had a patent ductus arteriosus, present at baseline evaluation. 


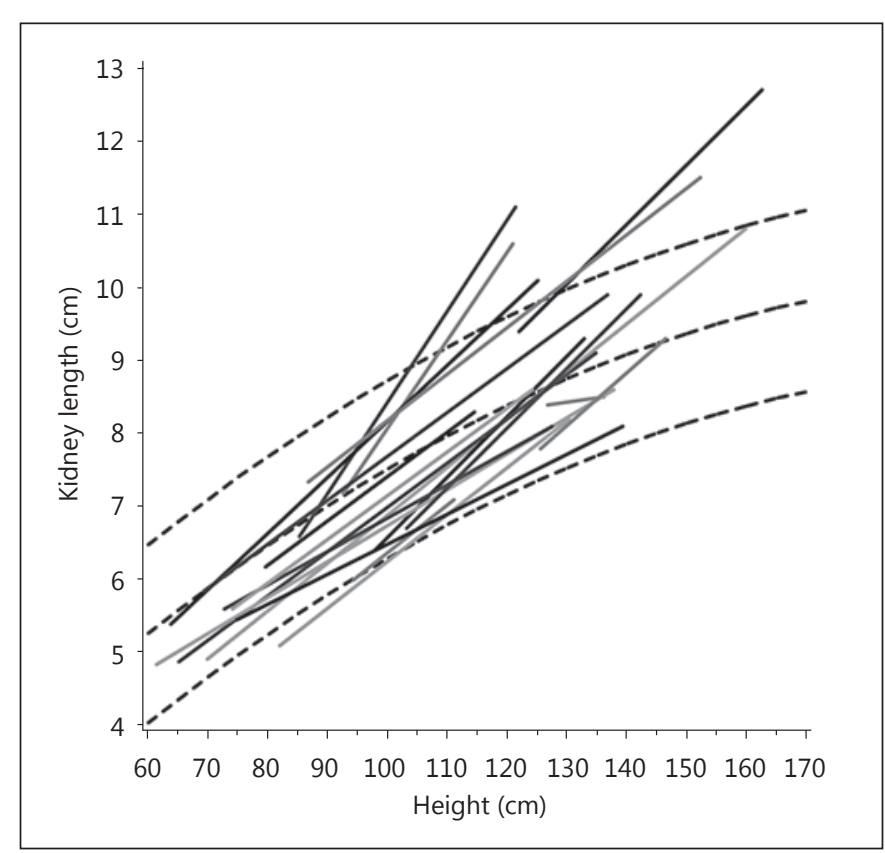

Fig. 5. Kidney length (using the mean for right and left renal lengths) versus height in patients with adult/near-adult height after long-term therapy with IGF-I. Solid lines represent kidney growth from first to last observation for each patient. Dashed curves indicate normal mean and mean \pm 2 SD scores, based on Han and Babcock [38].

Another patient had a small patent foramen ovale (not detected at baseline) with left-to-right shunting, plus transient mild mitral insufficiency. Neither finding was thought to be related to the IGF-I therapy. Two other patients were noted with tricuspid insufficiency at their last echocardiogram. Three of the study participants were noted to have supranormal left ventricular systolic performance at one or more of their follow-up echocardiogram tests, but subsequently were described as having this finding normalized.

\section{Laboratory Measurements}

As reported previously, there were frequent occurrences of hypoglycemia both before and after institution of IGF-I therapy [1]. However, the frequency of hypoglycemic events did not increase with IGF-I therapy. Normal insulin concentrations were observed when measured in a subset of patients during the first 2 years of therapy (mean $5.3 \pm 4.0 \mu \mathrm{U} / \mathrm{ml}$ at year 2 ). $\mathrm{HbA}_{1 \mathrm{c}}$ concentrations also remained normal during the first 4 years of therapy (4.9-5.5\%, normal: $4.4-6.1 \%, \mathrm{n}=18)$. At last measurement the mean $\mathrm{HbA}_{1 \mathrm{c}}$ was $4.9 \%(3.7-5.7 \%, \mathrm{n}=18)$. This excluded the value for 1 patient, treated for a total of ap- proximately 12 years, who developed type 2 diabetes mellitus during the last year of therapy $\left(\mathrm{HbA}_{1 \mathrm{c}}\right.$ of $9.1 \%$ at diagnosis).

Mean serum cholesterol was $157.4 \pm 30.8 \mathrm{mg} / \mathrm{dl}$ at baseline $(\mathrm{n}=18), 187.9 \pm 27.8 \mathrm{mg} / \mathrm{dl}$ at 10 years of therapy $(\mathrm{n}=8)$, and $173.3 \pm 50.6 \mathrm{mg} / \mathrm{dl}$ at year $15(\mathrm{n}=4)$. The total cholesterol ranges were 104-226, 138-228, and 115$238 \mathrm{mg} / \mathrm{dl}$, respectively. Although in the normal range for most subjects, a modest increase in cholesterol was thus noticeable for some patients. Triglyceride concentrations were also measured higher in some individual patients over time: baseline mean triglyceride concentration was $69.9 \pm 29.3 \mathrm{mg} / \mathrm{dl}$ (range $20-141, \mathrm{n}=18$ ), and increased to $122.5 \pm 34.2 \mathrm{mg} / \mathrm{dl}$ at 10 years (range $89-193, \mathrm{n}=8$ ), and $93.0 \pm 23 \mathrm{mg} / \mathrm{dl}$ at year 15 (range $73-118, \mathrm{n}=4$ ).

Serum electrolytes, urea nitrogen, creatinine, albumin, total protein, liver transaminases, and bilirubin remained normal throughout the study. Lactate dehydrogenase (LDH) was normal at baseline (mean $290.7 \pm 65 \mathrm{IU} / \mathrm{l}$, $\mathrm{n}=16$, mean age 6 years) and varied appropriately with age (mean LDH of $222.6 \pm 46.7 \mathrm{IU} / \mathrm{l}$ at laboratory year 4 , mean age 11 years, $\mathrm{n}=14$ ). There were some patients, later into treatment, who had isolated mild LDH elevation (range 445-602, $n=3$, year 15). Thyroid-stimulating hormone remained normal for all patients in each study year. Hematologic parameters were also normal, but we observed an increase in red cell indices over the course of the study, likely due to increasing age and androgen effect (adrenarche and/or puberty).

\section{Adverse Events}

The adverse events of relevance are listed in online suppl. table 1. We did not observe any new such adverse events compared with what was previously reported for the larger patient population [1].

\section{Discussion}

Prior studies, further substantiated by isolated case reports, have shown that IGF-I is effective in promoting statural growth in children with severe IGFD $[1,6-9,14-$ 16]. The present study defines the clinical course for such children undergoing long-term treatment until (near) adult height is reached. We have found, as have others, that the first-year growth response is typically close to a near tripling of the baseline height velocity with optimal dosing of IGF-I. In fact, our reported first-year height velocity was likely conservative because 3 patients were drawn from an initial study protocol where they received 
active treatment for less than the full year (either 6 or 9 of the 12 months). Consequently, their mean dose used during the first year of therapy $(90 \mu \mathrm{g} / \mathrm{kg} /$ dose twice daily) was about $25 \%$ less than the recommended maximum dose $(120 \mu \mathrm{g} / \mathrm{kg} /$ dose twice daily). Omitting these 3 patients from calculation results in a first-year height velocity of $7.6 \mathrm{~cm} /$ year (compared to $7.4 \mathrm{~cm} /$ year). We also found that the growth-promoting effects of IGF-I persist for many years thereafter. Our subjects grew at approximately normal height velocities after the first 2-3 years of IGF-I treatment. With a growth rate that merely remained close to the normal range, they had no additional catchup growth after the initial years and most patients did not achieve adult heights in the normal range. Nevertheless, their adult heights are greater than expected - based on previously reported untreated patients - as they continued to grow well for their primary diagnosis [12]. One caveat regarding the method used to estimate expected adult height (without IGF-I treatment) is that the Laron syndrome curves are based on a limited number of patients and extrapolation of height gain over that expected may not be entirely applicable. In addition, Laron syndrome growth charts do not account for differences in patients' ethnicity or underlying genetic diagnosis either. However, given the rarity of the conditions associated with severe IGFD, it is still the best information available [12]. Though the positive effects of IGF-I treatment are indisputable, the overall growth response in severe IGFD patients to long-term IGF-I therapy remains below what has been observed when GH-deficient patients are treated with GH, and in whom a normal adult height is often achieved [17]. There are several potential explanations for this. First, the actions of IGF-I involve both endocrine as well as paracrine/autocrine mechanisms $[18,19]$. With subcutaneously administered IGF-I therapy, we mainly restore the endocrine component of the GH/IGF-I axis. Because locally produced IGF-I is crucial for optimization of linear growth, the therapeutic effect of exogenously administered IGF-I is limited. Second, studies of genetically altered mice have clearly shown the importance of both GH and IGF-I in postnatal growth, with synergistic as well as overlapping functions [20]. This may or may not exactly correlate with findings in humans, but, in our patients, the direct actions of GH remain absent during IGF-I monotherapy. Third, the subjects have very low concentrations of IGFBP-3 and acid-labile subunit, which are unaltered during IGF-I therapy [7]. Thus, the therapeutic exposure to IGF-I may be reduced in this situation because the clearance of exogenously administered recombinant human IGF-I is accelerated. Finally, a compo- nent of decreased compliance may also have contributed to this diminished treatment response. For certain patients, intermittently throughout the duration of the study, there were periods when adherence to the treatment recommendations was suboptimal.

Puberty is typically delayed in untreated patients with GH receptor deficiency [21]. This was also seen within this patient cohort, as only 1 of the subjects had onset of puberty prior to when IGF-I therapy was started. We then observed that several of our patients began puberty at a normal age, prompting the introduction of $\mathrm{GnRH}$ analog therapy to prolong the time for growth. This effect of IGF-I on pubertal maturation has been reported $[22,23]$ and is consistent with the observation that GH therapy shortens the duration of puberty in $\mathrm{GH}$-deficient patients [24]. In this study, the patients additionally treated with GnRH analog therapy had a slightly better response (similar $\Delta$ height SD score with less BA change) than those patients treated with IGF-I alone, even though the additional $\mathrm{GnRH}$ analog treatment was begun relatively late in the course of puberty for some. We also observed a slowing of the height velocity in some patients while on GnRH analog therapy, which partially resolved when the IGF-I dose was increased to $150 \mu \mathrm{g} / \mathrm{kg} /$ dose twice daily. This has been observed in a patient with Laron syndrome who experienced an almost complete arrest of growth during similar combination treatment [16]. Combined treatment with IGF-I + GnRH analog therapy still may improve height outcome in IGFD patients if such therapy is started at the onset of puberty. Furthermore, we did not observe additional catch-up growth at the onset of puberty. This may again be related to an ongoing lack of direct GH effect, as it has long been established that sex steroids exert their full growth-promoting action only in the presence of normal GH concentrations [25].

Our long-term observations raise no new concerns about the frequency or nature of adverse effects of IGF-I treatment in children with severe primary IGFD. We observed a modest gain in fat mass as previously reported $[6$, 7]. This may be a result from intermittent, high free IGF-I concentrations after each injection. The insulin-like effect of IGF-I on adipocytes, stimulating fat cell growth/lipogenesis, has been observed only at high IGF-I concentrations and is believed to be mediated via cross-reactivity with the insulin receptor, as IGF-I receptors are not present on adipose cells [26-28]. We did not find overgrowth of specific organs for which there had been a concern based on data in rats treated with IGF-I [29]. Heart, kidneys and spleen underwent age-appropriate changes in most patients. As described, several patients demonstratDOI: $10.1159 / 000351958$
Backeljauw/Kuntze/Frane/Calikoglu/ Chernausek 
ed more robust renal growth. Because some of these patients also had better linear growth, it is possible that longer duration of IGF-I therapy, better compliance, or increased IGF-I sensitivity affected these patients' renal growth. Hypoglycemia, documented or reported based on clinical suspicion, was frequent but not different than previously reported and often due to the underlying condition rather than the IGF-I treatment [1]. The appearance of benign intracranial hypertension has been previously reported both during GH therapy and therapy with IGF-I [30-32]. The mechanism for this is most likely an increase in the production of cerebrospinal fluid from the choroid plexus, mediated by an increase in IGF-I concentration [33]. The cases identified in this report were reported previously [1]. Although most cases of intracranial hypertension are benign and treatment is straightforward with complete reversibility of the increased intracranial pressure, education of both treating physicians and caregivers about intracranial hypertension seems essential. Features attributable to growth of the nasopharyngeal lymphoid tissues were observed as before [1]. This included snoring and hypoacusis. Audiology monitoring predominantly revealed intermittent conductive hearing loss with/without decreased tympanic membrane compliance on tympanometry (data were not shown). We continued to observe maturational and coarsening changes in some participants' facial appearance, with the most significant changes presenting during puberty [34]. Although previously a concern, long-term IGF-I therapy was not accompanied by acromegaloid overgrowth of the facial bony structures $[35,36]$. Furthermore, the observed soft tissue enlargement of the face improved considerably after discontinuation of IGF-I therapy.

In summary, the efficacy and safety of IGF-I therapy in patients with severe IGFD has been evaluated for almost two decades. In such patients, IGF-I doses of $120 \mu \mathrm{g} / \mathrm{kg}$ twice daily by subcutaneous injection induce significant increases in height velocity and height SD score, maintained with prolonged treatment until adult/ near-adult height. Although most subjects do not experience catch-up growth sufficient to bring their heights into the normal range, many patients have achieved an adult height significantly greater than expected in the absence of therapy. Long-term IGF-I therapy, therefore, appears to be effective and relatively safe as a replacement therapy in children with short stature due to severe IGFD. The availability of IGF-I has been an important development for the management of such patients. Because the spectrum of GH insensitivity is wider than the patients reported upon in this study, further investigation into the therapeutic applicability of IGF-I in patients with varying degrees of IGFD is warranted [37].

\section{Acknowledgements}

The authors would like to recognize the significant contribution made to this study by Dr. Louis Underwood, who was instrumental in the development and implementation of the original study protocol. They also would like to express their gratitude towards Vinnie Duncan and Samantha Blum for their contributions in the role of study coordinator throughout the duration of this study.

This work was supported by general clinical research center grants M01RR08084 (Cincinnati Children's Hospital Medical Center) and RR00046 (University of North Carolina at Chapel Hill), and by Genentech, Inc., Tercica, Inc. and Ipsen Biopharmaceuticals, Inc.

\section{Disclosure Statement}

P.F.B., A.S.C. and S.D.C. have received research support and advisory board or lecture fees from Ipsen Biopharmaceuticals, Inc. J.F. has received consulting fees from Ipsen Biopharmaceuticals, Inc. J.K. has received salary and consultant fees from Ipsen Biopharmaceuticals, Inc.

\section{References}

1 Chernausek SD, Backeljauw PF, Frane J, Kuntze J, Underwood, LE: Long-term treatment with recombinant insulin-like growth factor (IGF)-I in children with severe IGF-I deficiency due to growth hormone insensitivity. J Clin Endocrinol Metab 2007;92:902-910.

2 Backeljauw PF: Diagnosis and management of primary insulin-like growth factor-I deficiency: current perspectives and clinical update. Pediatr Endocrinol Rev 2010;7(suppl 1):154-171.

-3 Lupu F, Terwilliger JD, Lee K, Segre GV, Efstratiadis A: Roles of growth hormone and insulin-like growth factor-1 in mouse postnatal growth. Dev Biol 2001;229:141-162.

4 Rosenfeld RG, Hwa V: New molecular mechanisms of GH resistance. Eur J Endocrinol 2004;151(suppl 1):S11-S15.

5 Wit JM: Diagnosis and management of disorders of IGF-I synthesis and action. Pediatr Endocrinol Rev 2011;9(suppl 1):538-540.

6 6 Ranke MB, Savage MO, Chatelain PG, Preece MA, Rosenfeld RG, Wilton P: Long-term treatment of growth hormone insensitivity syndrome with IGF-I. Results of the Europe- an Multicentre Study. The Working Group on Growth Hormone Insensitivity Syndromes. Horm Res 1999;51:128-134.

7 Backeljauw PF, Underwood LE: Therapy for 6.5-7.5 years with recombinant insulin-like growth factor I in children with growth hormone insensitivity syndrome: a clinical research center study. J Clin Endocrinol Metab 2001;86:1504-1510.

8 Klinger B, Laron Z: Three year IGF-I treatment of children with Laron syndrome. J Pediatr Endocrinol Metab 1995;8:149-158. 
$\$ 9$ Guevara-Aguirre J, Rosenbloom AL, Vasconez O, Martinez V, Gargosky SE, Allen L, Rosenfeld RG: Two-year treatment of growth hormone $(\mathrm{GH})$ receptor deficiency with recombinant insulin-like growth factor I in 22 children: comparison of two dosage levels and to GH-treated GH deficiency. J Clin Endocrinol Metab 1997;82:629-633.

10 Roche AF, Chulmea CW, Thissen D: Assessing the Skeletal Maturity of the Hand-Wrist: FELS Method. Springfield, Thomas, 1988.

-11 Kuczmarski RJ, Ogden CL, Grummer-Strawn LM, Flegal KM, Guo SS, Wei R, Mei Z, Curtin LR, Roche AF, Johnson CL: CDC growth charts: United States. Adv Data 2000;314:1-27.

12 Laron Z, Lilos P, Klinger B: Growth curves for Laron syndrome. Arch Dis Child 1993;68: 768-770.

13 Rosenberg HK, Markowitz RI, Kolberg A, Park C, Hubbard A, Bellah RD: Normal splenic size in infants and children; sonographic measurements. Am J Roentgenol 1991;157:119-121.

-14 Concolino D, Muzzi G, Sestito S, Vega G, Bonapace G, Strisciuglio P: Long-term treatment with recombinant insulin-like growth factor 1 (IGF-1) in a child with IGF-1 gene mutation. Eur J Pediatr 2010;169:245-247.

15 Heinrichs C, Vis HL, Bergmann P, Milton P, Bourguignon JP: Effects of 17 months treatment using recombinant insulin-like growth factor-I in two children with growth hormone insensitivity (Laron) syndrome. Clin Endocrinol (Oxf) 1993;38:647-651.

16 Zucchini S, Scarano E, Baldazzi L, Mazzanti L, Pirazzoli P, Cacciari E: Final height in a patient with Laron syndrome after long-term therapy with rhIGF-I and short-term therapy with LHRH analogue and oxandrolone during puberty. J Endocrinol Invest 2005;28:274-279.

17 Vance ML, Mauras N: Growth hormone therapy in adults and children. N Engl J Med 1999; 341:1206-1216.

18 Yakar S, Liu JL, Fernandez AM, Wu Y, Schally AV, Frystyk J, Chernausek SD, Mejia W, Le Roith D: Liver-specific IGF-1 gene deletion leads to muscle insulin insensitivity. Diabetes 2001;50:1110-1118.
19 Sjögren K, Liu J, Blad K, Skrtic S, Vidal O, Wallenius V, LeRoith K, Torn ell J, Isaksson OGP, Jansson JO, Ohlsson C: Liver-derived insulin-like growth factor I (IGF-I) is the principal source of IGF-I in blood but is not required for postnatal body growth in mice. Proc Natl Acad Sci USA 1999;96:7088-7092.

20 Lupu F, Terwilliger JD, Lee K, Segre GV, Efstratiadis A: Roles of growth hormone and insulin-like growth factor 1 in mouse postnatal growth. Dev Biol 2001;229:141-162.

21 Pertzelan A, Lazar L, Klinger B, Laron Z: Puberty in 15 patients with Laron syndrome: a longitudinal study; in Laron Z, Parks JS (eds): Lessons from Laron syndrome 1966-1992: a model of GH and IGF-I action and interaction. Pediatr Adolesc Endocrinol 1993;24:2733.

22 Laron Z, Klinger B: Effect of insulin-like growth factor-I treatment on serum androgens and testicular and penile size in males with Laron syndrome (primary growth hormone resistance). Eur J Endocrinol 1998;138: 176-180.

23 Laron Z: Laron syndrome (primary growth hormone resistance or insensitivity): the personal experience 1958-2003. J Clin Endocrinol Metab 2006;89:1031-1044.

24 Darendeliler F, Hindmarsh PC, Preece MA, Cox L, Brook CGD: Growth hormone increases rate of pubertal maturation. Act Endocrinol (Copenh) 1990;122:414-416.

25 Aynsley-Green A, Zachmann M, Prader A: Interrelation of the therapeutic effects of growth hormone and testosterone on growth in hypopituitarism. J Pediatr 1976;89:992999.

26 Zapf J, Scheele E, Wald Vogel M, Sand I, Frisch ER: Effect of trypsin treatment of rat adipocytes on biological effects and binding of insulin and insulin-like growth factors: further evidence for the action of insulin-like growth factors through the insulin receptor. Eur J Biochem 1981;113:605-609.

27 Blinder J, Landlady A, Enfold P, Earner P: Studies of acute effects of insulin-like growth factors I and II in human fat cells. J Clin Endocrinol Metab 1987;65:732-737.

28 LeRoith D, Yakar S: Mechanisms of disease: metabolic effects of growth hormone and insulin-like growth factor 1. Nat Clin Pract Endocrinol Metab 2007;3:302-310.

29 Guler HP, Zapf J, Scheiwiller E, Froesch ER: Recombinant human insulin-like growth factor-I stimulates growth and has distinct effects on organ size in hypophysectomized rats. Proc Natl Acad Sci USA 1988;85:48894893.
30 Noto R, Maneatis T, Frane J, Alexander K, Lippe B, Davis DA: Intracranial hypertension in pediatric patients treated with recombinant human growth hormone: data from 25 years of Genentech National Cooperative Growth Study. J Pediatr Endocrinol Metab 2011;24: 627-631.

31 Lordereau-Richard I, Roger M, Chaussain JL: Transient bilateral papilledema in 10-yearold boy treated with recombinant insulin-like growth factor I for growth hormone receptor deficiency. Acta Paediatr Suppl 1994;399:152.

32 Midyett LK, Rogol AD, Van Meter QL, Frane J, Bright GM: Recombinant insulin-like growth factor (IGF)-I treatment in short children with low IGF-I levels: first-year results from a randomized clinical trial. J Clin Endocrinol Metab 2010;95:611-619.

33 Johansson JO, Larson G, Anderson M, et al: Treatment of growth hormone-deficient adults with recombinant human growth hormone increases the concentration of growth hormone in the cerebrospinal fluid and affects neurotransmitters. Neuroendocrinology 1995;61:57-66.

34 Klinger B, Anin S, Silbergeld A, Eshet R, Laron $\mathrm{Z}$ : Development of hyperandrogenism during treatment with insulin-like growth factor-I in female patients with Laron syndrome. Clin Endocrinol (Oxf) 1998;48:81-87.

35 Leonard J, Samuels M, Cotterill AM, Savage MO: Effects of recombinant insulin-like growth factor-I on craniofacial morphology in growth hormone insensitivity. Acta Paediatr Suppl 1994;399:140-141.

36 Backeljauw PF, Kissoondial A, Underwood LE, Simmons KE: Effects of 4-years treatment with recombinant human insulin-like growth factor I (RhIGF-I) on craniofacial growth in children with growth hormone insensitivity syndrome (GHIS). Horm Res 1997;48:(suppl 2):40.

37 David A, Hwa V, Metherell LA, et al: Evidence for a continuum of genetic, phenotypic, and biochemical abnormalities in children with growth hormone insensitivity. Endocr Rev 2011;32:472-497.

-38 Han BK, Babcock DS: Sonographic measurements and appearance of normal kidneys in children. AJR Am J Roentgenol 1985;145: 611-616. 